\title{
Adieu, James Crawford
}

\author{
Alain Pellet \\ Emeritus Professor, Faculty of Law, University Paris Nanterre, Nanterre, \\ France; President, Institut de droit international, Geneva, Switzerland \\ courriel@alainpellet.eu
}

This brief contribution does not aim to present the exceptionally brilliant and rich career of my friend and "accomplice in international law", James Crawford, to whom international law owes so much. I will rather try to pay tribute to the man he was through our professional relations, which were diverse and extremely dense.

We met in unusual circumstances, in the autumn of 1991, during the pleadings in the Nauru case. It was unusual because, although he was Australian - and he was very much so! - he was part of the Nauru team, following in the footsteps of his master, Ian Brownlie, whereas I had been drawn into the Australian team by Derek Bowett, whom he joined on the Libyan team (in the Aouzou Strip case), while I was on Chad's team. Everything went back to normal on the occasion of the East Timor team: he joined his motherland - we were both pleading for Australia! - this is a small world. Brownlie called it the "ICJ mafia", and, indeed, both James and I soon became mafiosi ... Thereafter, our paths crossed many, many times: we pleaded 14 cases against each other and six cases together before the ICJ (as well as three against each other and together before other international tribunals). And our friendship grew and strengthened over the years.

We were different but quite complementary in many ways. One example of this (anecdotal as it is) is famous with the "mafia": James was an early sleeper; I am a night owl. When we worked together in a counsel team, he would pass his draft pleadings under my hotel room door (often no later than ten o'clock at night), and I would read them over, mark them up, and slip them back under his door at about four o'clock in the morning. In the same line, James was a cordon bleu, and he would treat his guests to dinner when he invited friends over, but we ate early and he would usually give the signal to leave by 9 PM. Eating together (and sometimes touring together) under the pretext of working visits is part of the job in some international cases. I have dear recollections of such 
travels with James, notably along the Cambodia-Thailand boundary, or in the Danube Delta. He was, indeed, a good companion.

By the way, a word about the teamwork which is so fundamental in these big machines that are the advocacy teams before the ICJ. One of James' greatest professional qualities (he had many) was that he was a fantastic team player. He was not particularly patient (and his calls to order - with a loud "Order!" during team meetings were famous). But he was a good listener and, even if he was not particularly indulgent, he was fair and very eager to encourage young talent. And he was helpful: he was critical, but constructive, and he was prepared to question himself in the interests of the case and the consistency of the argument.

One thing that always struck me about him was that, while he was a common law lawyer, he was aware that international law is a mixture of common law and continental law and that, when one pleads before a large court such as the International Court of Justice or the International Tribunal for the Law of the Sea, one has to convince judges of different backgrounds from each of these two systems. He was therefore particularly careful to avoid the legal parochialism, which - I dare say - sometimes characterises our Anglo-Saxon colleagues (especially the British!), although there are of course brilliant exceptions ... Clearly, he was one of those exceptions.

And ... he was not British! As I have already said, he was terribly - or wonderfully - Australian. Anecdotally, during the hearings in the East Timor case, James adamantly refused to wear the wig, emphatically pointing out that he was Australian - prompting a saddened reaction from Derek Bowett, who sighed: "What a disgrace!".

One of our favourite conversations, when we were not talking about our children and wives or the comparative merits of French and Thai cuisines, was about the respective approaches to international law and the style of advocacy before international courts and tribunals of common lawyers as compared with that of continental lawyers. There are written records of this disputatio. We could differ, but we greatly respected each other's ways of thinking and pleading. ${ }^{1}$ As for the latter, his somewhat brutal style was always tempered by respect for his opponents and a great sense of humour. I will not go into the jokes that were part of many of his pleadings: it would be endless. But jokes, if

1 See especially: J. Crawford and A. Pellet, "Anglo Saxon and Continental Approaches to Pleading Before the ICJ", in International Law Between Universalism and Fragmentation Festschrift in Honour of Gerhard Hafner (Leiden-Boston: Nijhoff, 2008), 831-867; or J. Crawford, A. Pellet and C. Redgwell, "Anglo-American and Continental Traditions in Advocacy before International Courts and Tribunals", 2(4) Cambridge Journal of International and Comparative Law (2013), 1-23. 
they are targeted and understood by all, are part of the job. As he said during one of our debates: "You do not tell jokes in the Court, but you do want to keep [the judges] awake." Both of us agreed: whereas oral pleadings are indispensable, they usually are very boring.

When James decided to run for the elections to become a judge, we had a rather long discussion, and I must say, with all due respect to the Bench, that I find it rather more exciting to act as counsel than to sit as a judge. I can say (now!) that he tended to share this view. However, I understood his personal reasons and was happy for him when he was brightly elected. But I very much missed him as a co-counsel - all the more so as his new position made for our relations, while still very friendly, becoming a little strained following his election. I had, nonetheless, seven occasions to plead before him; even though he had to recuse himself in some cases, since he had been such a frequent and successful advocate involved in so many cases concerning so many States. We had a small dispute on one occasion when I was of the opinion that he should have recused himself, but I conceded that it must be particularly frustrating to be a spectator when you belong to a court with, regrettably, few cases to decide. He was not a man of inactivity and he continued to write and publish, never forgetting that he was a professor in spite of his eminent position as a judge.

James was a prodigious worker, and he carried out many different activities at the same time, without sparing himself and ... without always sparing his collaborators. But he was much loved by them and I must say that I always admired his leadership skills. He ran the Lauterpacht Centre for International Law in Cambridge with great success and an impressive capacity to coordinate sometimes very large teams. I was told that he prepared his General Course at the Hague Academy with about twenty assistants. I am all the more admiring as I find it difficult to lead a team of more than two or three members! But it must be emphasized that, at the end of the day, the result, whether it was a book, an article, a course or a pleading, was always James Crawford's.

This was particularly striking with respect to the breath-taking amount of time James spent on the International Law Commission, where he served from 1992 to 2001. He took on, as Special Rapporteur, two huge projects: the draft Statute of the International Criminal Court; and the one that led to the adoption, in 2001, of the rightly celebrated Articles on State Responsibility, where his pragmatism, hard work, ability to listen and sense of compromise worked wonders.

He was a bit of a steamroller in the sense that, once he had set his goal, there was no way to stop him - and he did reach it. But he was flexible and openminded enough to reconcile points of view. And I am proud to have convinced 
him on a number of points - perhaps because he did not attach much importance to them -: he clearly did not want to get bogged down in theoretical debates that would have delayed the adoption of the project beyond the end of his mandate. This was particularly striking with regard to the fate of the concept of international "crime", i.e. the follow-up to Roberto Ago's famous draft Article 19. Initially, his pragmatism had led him to propose, in his first Report, to purely and simply leave the subject out of the draft; he came up against fairly lively opposition (of which I must say I was a member); he then put the question aside and only reintroduced it quite late in the process (a rather clever way of putting pressure on the Commission ...), but by proposing a compromise solution that was finally acceptable to all the members: it is reflected in Articles 40 and 41 of the 2001 Articles, which, in fact, take up the essence of the former Article 19 but without waving the red rag "crime".

I would like to end on a personal note. James did not always have an easy life and he did not always make it easy for himself in his quest for happiness, which might have been a sort of Ariadne's thread that guided him throughout his entire life. But he always took it all on board, including during the last two years: when, accompanied by his wife, he faced terrible ills with exemplary courage. And, in this time of remembrance, I have a special thought for his children, to whom he has always been a caring and affectionate father, beyond the vicissitudes of life. For, despite the appearance (perhaps a little gruff) that he sometimes gave, James Crawford, my old friend, was a tender and kindhearted man. 